\title{
PENILAIAN MODUL APRESIASI MENGHIAS KAIN MATERI SULAMAN LEKAPAN
}

Gadis Rahmayanti ${ }^{1}$, Vivi Radiona ${ }^{2}$, Harsuyanti Rawiyah Lubis ${ }^{3}$

\author{
Afiliasi \\ ${ }^{123}$ Pendidikan Tata Busana, \\ Universitas Negeri Jakarta
}

\section{Contributor email :}

Jl. Rawamangun Muka Raya No.11, RT.11/RW.14, Rawamangun, Jakarta Timur 13220

E-mail: gadisrahmayanti2@gmail.com

\section{ABSTRAK}

Penelitian ini bertujuan untuk membuat Modul Mata Kuliah Apresiasi Menghias Kain Materi Sulaman Lekapan kemudian dilakukan penilaian kepada panelis ahli. Metode yang digunakan dalam penelitian ini adalah metode Pre-Experimental dengan bentuk desain One Shot Case Study. Teknik analisis data yang digunakan adalah Kuantitatif Deskriptif. Teknik pengumpulan data menggunakan angket (kuesioner) tertutup-terbuka (campuran) kepada Panelis Ahli dengan menggunakan indikator dari karakteristik modul yang meliputi aspek Self Intruction, Self Contained, Stand Alone, Adaptive, User Friendly, dan juga menggunakan indikator dari elemen mutu modul yang meliputi aspek format, organisasi, daya tarik, bentuk dan ukuran huruf, ruang (spasi kosong), dan konsistensi. Hasil dari penelitian penilaian modul sulaman lekapan berdasarkan karakteristik modul oleh 2 panelis ahli mendapat persentase sebesar 90,75\% dan penilaian modul sulaman lekapan berdasarkan elemen mutu modul oleh 2 panelis ahli mendapat persentase sebesar 92,25\%. Kemudian secara keseluruhan penilaian modul apresiasi menghias kain materi sulaman lekapan mendapat nilai persentase sebesar $91,5 \%$ sehingga modul berada dalam kategori sangat baik.

Kata Kunci: Penilaian, Modul, Sulaman Lekapan

\section{ABSTRACT}

This research aims to make the Appreciation Course Module for Embroidery Fabric Appreciation and then evaluate the expert panelists. The method used in this research is the Pre-Experimental method with the form of One Shot Case Study design. The data analysis technique used is descriptive quantitative. The data collection technique uses a closed-open (mixed) questionnaire to the Expert Panelists using indicators from module characteristics which include aspects of Self Instruction, Self Contained, Stand Alone, Adaptive, User Friendly, and also uses indicators from module quality elements which include aspects of format, organization, attractiveness, font shape and size, space (blank space), and consistency. The results of the research on the assessment of the embroidery module based on the characteristics of the module by 2 expert panelists got a percentage of $90.75 \%$ and the assessment of the embroidery module based on the quality elements of the module by 2 expert panelists got a percentage of $92.25 \%$. Then the overall assessment of the appreciation module for decorating embroidered embroidered fabrics got a percentage value of 91.5\% so that the module was in the very good category.

Keywords: Assessment, Module, Embroidery

\section{A. PENDAhuluan}

Sistem pembelajaran merupakan hal penting dalam dunia pendidikan, memiliki fasilitas yang mampu menunjang keterampilan $4 \mathrm{C}$ dalam proses pembelajaran menjadi sangat penting pada abad ke-21 ini. Dalam proses pembelajaran, terdapat komponen penting yang dimana semua komponen lain mengacu pada komponen tersebut, dan komponen yang dimaksud adalah tujuan pembelajaran. Untuk dapat mendukung berjalannya kegiatan 
pembelajaran dan membantu tercapainya tujuan pembelajaran, maka dibutuhkan sumber belajar yang mampu membantu dosen dalam menjelaskan materi pembelajaran serta membantu mahasiswa memahami materi yang dipelajari.

Salah satu sumber belajar yang dapat digunakan dalam kegiatan pembelajaran adalah bahan ajar. Terdapat beberapa jenis bahan ajar diantaranya ialah modul, Lembar Kerja Siswa (LKS), handout, buku teks (buku paket) dan lain sebagainya (Wulansari et al., 2018). Pemilihan bahan ajar yang tepat untuk digunakan pada saat melaksanakan kegiatan pembelajaran, dapat mendukung kelancaran proses belajar dan membantu tercapainya tujuan pembelajaran serta membantu mahasiswa untuk bisa belajar secara mandiri. Oleh karena itu, bahan ajar yang akan dibuat dalam penelitian ini adalah modul. Karena modul merupakan salah satu bahan ajar yang dapat dipelajari secara mandiri oleh mahasiswa. Modul juga dapat digunakan kapanpun dan dimanapun sesuai dengan kebutuhan mahasiswa (Fatimah \& Ramadhana, 2017).

Mata kuliah Apresiasi Menghias Kain merupakan salah satu mata kuliah pada program studi Pendidikan Tata Busana di Universitas Negeri Jakarta. Terdapat berbagai macam jenis sulaman yang dibahas pada mata kuliah Apresiasi Menghias Kain dan salah satunya ialah teknik menghias pada kain tenun rapat. Beberapa sulaman yang digunakan untuk menghias kain tenun rapat yaitu sulaman fantasi, sulaman bebas, sulaman lekapan dan sulaman melekatkan (Harsuyanti, 2020). Namun karena adanya keterbatasan waktu yang dialami oleh peneliti, maka pada penelitian ini peneliti hanya akan membahas mengenai materi sulaman lekapan yaitu sulaman aplikasi dalam modul yang akan dibuat.

Menurut dosen pengampu Apresiasi Menghias Kain dalam wawancara bersama peneliti, yang menyatakan bahwa sumber belajar yang digunakan oleh dosen dalam proses pembelajaran Apresiasi Menghias Kain adalah buku Embroidery. Selain itu terdapat perubahan jumlah SKS pada mata kuliah Apresiasi Menghias Kain dari 4 SKS menjadi 3 SKS yang menyebabkan berkurangnya waktu pembelajaran. Adapun metode pembelajaran yang digunakan adalah metode demonstrasi, dosen akan mendemokan serta mempraktikkan Langkah-langkah teknik menghias kain kepada mahasiswa. Lalu agar mahasiswa dapat mempelajari ulang mengenai teknik menghias kain di rumah, dosen menyediakan video-video tutorial yang di upload di YouTube, yang dimana video tutorial tersebut dapat diakses secara online.

Oleh sebab itu, peneliti akan membuat bahan ajar berupa modul cetak materi sulaman lekapan yaitu sulaman aplikasi sebagai tambahan sumber belajar yang dapat digunakan oleh mahasiswa secara offline. Selain itu, penggunaan modul cetak dapat menunjang keterampilan abad 21 seperti keterampilan memecahkan masalah, berpikir kritis dan berpikir kreatif (Puspitasari, 2019). Sehingga diharapkan modul cetak yang akan dibuat ini dapat mempermudah mahasiswa dalam memahami materi sulaman lekapan yaitu sulaman aplikasi dan mendukung berjalannya proses pembelajaran serta membantu tercapainya tujuan pembelajaran pada mata kuliah Apresiasi Menghias Kain.

Menurut Ismu Fatikhah dan Nurma Izzati (2015) Karakteristik yang harus diperhatikan dalam membuat modul adalah Self Intruction, Self Contained, Stand Alone, Adaptive, dan User Friendly. Lalu, modul juga perlu dirancang dan dikembangkan dengan memperhatikan beberapa elemen, yaitu format, organisasi, daya tarik, ukuran huruf, spasi kosong, dan konsistensi (Rahdiyanta, 2016). Maka dari itu, dalam pembuatan modul cetak materi sulaman lekapan pada penelitian ini akan dibuat dengan memperhatikan dan memenuhi karakteristik modul serta elemen mutu modul. 
Berdasarkan pemaparan latar belakang yang telah diuraikan di atas, peneliti tertarik untuk melakukan penelitian dengan judul "Penilaian Modul Apresiasi Menghias Kain Materi Sulaman Lekapan" dimana dalam penelitian tersebut, peneliti akan membuat modul yang akan dinilai oleh panelis ahli berdasarkan dengan karakteristik modul yang baik dan elemen mutu modul.

\section{B. METODOLOGI}

Penelitian ini bertujuan untuk membuat modul pada mata kuliah Apresiasi Menghias Kain materi Sulaman Lekapan yaitu sulaman aplikasi, kemudian dinilai oleh panelis ahli untuk memperoleh data tentang penilaian modul sulaman lekapan yang dibuat. Tempat pelaksanaan penelitian ini dilakukan di Program Studi Pendidikan Tata Busana Universitas Negeri Jakarta dari bulan September 2021 hingga Februari 2022. Penelitian ini menggunakan metode Pre-Experimental, dengan bentuk desain One Shot Case Study yaitu metode preeksperimen yang dilakukan tanpa adanya kelompok pembanding dan juga tanpa adanya tes awal (pretest). One Shot Case Study merupakan desain penelitian yang terdiri dari suatu kelompok yang diberi treatment atau perlakuan dan hasilnya di observasi (Sugiyono, 2019).

Tabel 2.1 Tabel Pre-Experimental

\begin{tabular}{|c|c|}
\hline$x$ & 0 \\
\hline $\begin{array}{l}\text { Pembuatan Modul } \\
\text { Apresiasi }\end{array}$ & $\begin{array}{l}\text { Penilaian Modul } \\
\text { Apresiasi Menghias }\end{array}$ \\
\hline Menghias & Kain \\
\hline $\begin{array}{l}\text { Materi Sulaman } \\
\text { Lekapan }\end{array}$ & $\begin{array}{l}\text { Sulaman lekapan } \\
\text { oleh panelis ahli }\end{array}$ \\
\hline
\end{tabular}

Keterangan:

$\mathrm{X}=$ treatment atau perlakuan

$\mathrm{O}=$ hasil evaluasi sesudah treatment

Objek pada penelitan ini adalah modul apresiasi menghias kain materi sulaman lekapan dan subjek penelitian ini terdiri dari 4 orang panelis ahli untuk memberikan penilaian pada modul sulaman lekapan. Variabel penelitian ini adalah variabel tunggal yaitu penilaian modul apresiasi menghias kain materi sulaman lekapan.

Teknik pengumpulan data yang digunakan adalah angket tertutup-terbuka (campuran) yang akan diberikan kepada panelis ahli dengan menggunakan skala instrumen Rating Scale.

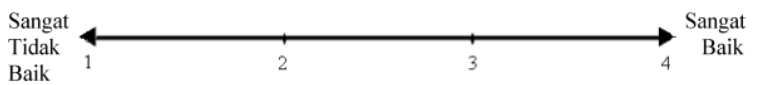

Gambar 2.1 Interval jawaban skala Rating Scale

Dimana panelis ahli menilai modul berdasarkan dengan indikator karakteristik modul yang meliputi aspek Self Intruction, Self Contained, Stand Alone, Adaptive, User Friendly. Dan juga menggunakan indikator dari elemen mutu modul yang meliputi aspek format, organisasi, daya tarik, bentuk dan ukuran huruf, ruang (spasi kosong), dan konsistensi. Kemudian, data yang diperoleh dari hasil penilaian oleh panelis ahli di analisa menggunakan teknik analisis kuantitatif dengan menggunakan pendekatan statistik deskriptif. 


\section{LANDASAN TEORI}

\section{Penilaian}

Menurut Dinny Devi Triana (2020) penilaian adalah suatu proses untuk mengambil keputusan dengan menggunakan informasi yang diperoleh melalui pengukuran, baik menggunakan instrumen tes maupun non-tes. Ditinjau dari aspek bahasa, penilaian yang lebih dikenal sebagai assessment dalam bahasa inggris memiliki arti tentang proses menentukan nilai dari suatu objek dengan adanya data-data yang diperoleh terlebih dahulu mengenai objek yang akan dinilai (Ofianto \& Ningsih, 2021).

Berdasarkan beberapa pendapat para ahli di atas, maka dapat disimpulkan bahwa penilaian adalah suatu proses kegiatan memberi nilai dengan menggunakan informasi berupa data yang diperoleh melalui pengukuran berdasarkan ktiteria tertentu baik menggunakan instrumen tes maupun non-tes. Dalam penelitian ini, peneliti akan melakukan penilaian modul menggunakan instrumen non-tes yaitu angket dengan berdasarkan aspek karakteristik modul dan elemen mutu modul.

\section{Modul}

Modul merupakan suatu alat atau sarana pembelajaran yang di dalamnya berupa materi, metode dan evaluasi yang dibuat secara sistematis dan terstruktur sebagai upaya mencapai tujuan kompetensi yang diharapkan (Prihatiningtyas \& Sholihah, 2020).

Pengertian Modul Menurut Zulhaini (2016) dalam buku yang ditulis oleh najuah (2020), modul adalah bahan ajar yang ditulis sendiri oleh pendidik untuk memudahkan siswa dalam mempelajari materi secara mandiri. Dalam dunia pendidikan saat ini, modul yang banyak dikembangkan ada dua jenis, yaitu modul elektronik dan modul cetak. Pengunaan modul elektronik maupun cetak didasarkan pada analisis permasalahan dan kebutuhan peserta didik.

Berdasarkan pendapat dari para ahli di atas dapat disimpulkan bahwa modul adalah suatu alat atau media pembelajaran berupa bahan ajar yang di dalamnya berisi materi, metode dan evaluasi yang dibuat secara sistematis dan terstruktur yang dapat dipelajari secara mandiri oleh siswa. Dalam penelitian ini, jenis modul yang akan dibuat oleh peneliti adalah modul cetak yang berisi mengenai materi sulaman lekapan yaitu sulaman aplikasi.

Menurut Daryanto (2013) karakteristik Modul yang mampu meningkatkan motivasi belajar peserta didik adalah sebagai berikut:

1. Self Instruction, merupakan karakteristik yang memungkinkan seseorang belajar secara mandiri dan tidak tergantung pada pihak lain.

2. Self Contained, modul dikatakan self contained bila seluruh materi pembelajaran yang dibutuhkan termuat dalam modul tersebut agar peserta didik dapat mempelajari materi pembelajaran secara tuntas, karena materi belajar dikemas kedalam satu kesatuan yang utuh.

3. Berdiri Sendiri (Stand Alone), Stand alone atau berdiri sendiri merupakan karakteristik modul yang tidak tergantung pada bahan ajar/media lain, atau tidak harus digunakan bersama-sama dengan bahan ajar/media lain.

4. Adaptif, Modul hendaknya memiliki daya adaptasi yang tinggi terhadap perkembangan ilmu dan teknologi. Dikatakan adaptif jika modul tersebut dapat menyesuaikan perkembangan ilmu pengetahuan dan teknologi, serta fleksibel/luwes digunakan di berbagai perangkat keras (hardware).

5. Bersahabat/Akrab (User Friendly), setiap instruksi dan paparan informasi yang tampil bersifat membantu dan bersahabat dengan pemakainya, termasuk kemudahan pemakai dalam merespon dan mengakses sesuai dengan keinginan. Penggunaan bahasa yang 
sederhana, mudah dimengerti, serta menggunakan istilah yang umum digunakan, merupakan salah satu bentuk user friendly.

Berdasarkan pemaparan karakteristik modul di atas, peneliti menggunakan teori karakteristik modul menurut Daryanto (2013) sebagai indikator penilaian oleh panelis ahli, yaitu Self Instructional, Self Contained, Stand Alone, Adaptive, dan User Friendly.

Menurut Daryanto (2013) Untuk menghasilkan modul pembelajaran yang mampu memerankan fungsi dan perannya dalam pembelajaran yang efektif, modul perlu dirancang dan dikembangkan dengan memperhatikan beberapa elemen, yaitu:

1. Format, gunakan format kolom (tunggal atau multi) yang proporsional, gunakan format kertas yang tepat, gunakan tanda-tanda (icon) yang mudah ditangkap.

2. Organisasi, organisasikan isi materi pembelajaran dengan urutan yang sistematis, susunan naskah, gambar dan ilustrasi yang mudah mengerti oleh peserta didik.

3. Daya Tarik, daya tarik modul dapat ditempatkan di bagian sampul (cover) depan, dan bagian isi modul.

4. Bentuk dan Ukuran Huruf, gunakan bentuk dan ukuran huruf yang mudah dibaca, gunakan perbandingan huruf yang proporsional, hindari penggunaan huruf kapital untuk seluruh teks.

5. Ruang (spasi kosong), gunakan spasi atau ruang kosong tanpa naskah atau gambar untuk menambah kontras penampilan modul. Spasi kosong dapat berfungsi untuk menambahkan catatan penting dan memberikan kesempatan jeda kepada peserta didik/peserta didik. Gunakan dan tempatkan spasi kosong tersebut secara proporsional.

6. Konsistensi pada penggunaan bentuk dan huruf, jarak spasi, dan tata letak pengetikan

Teori elemen mutu modul yang akan digunakan sebagai indikator penilaian oleh panelis ahli pada modul yang akan dibuat adalah elemen mutu modul menurut Daryanto (2013) yaitu format, organisasi, daya tarik, bentuk dan ukuran huruf, ruang (spasi kosong), dan konsistensi.

Unsur-unsur modul yang digunakan dalam pembuatan modul pada penelitian ini adalah unsur-unsur modul menurut Vembriarto (dalam Ramadhani et al., 2020) yang dapat disimpulkan bahwa modul memiliki 7 unsur yaitu rumusan tujuan instruksional khusus, petunjuk proses kegiatan pembelajaran, lembaran kegiatan belajar peserta didik, lembaran kerja atau tugas peserta didik, kunci jawaban, lembaran evaluasi, kunci dari lembaran evaluasi.

\section{Apresiasi Menghias Kain}

Apresiasi menghias kain adalah penilaian (penghargaan) terhadap nilai seni dalam memperelok atau memperindah suatu busana, lenan rumah tangga atau produk tekstil lainnya dengan memberikan ornament lain serta mempergunakan bermacam-macam tusuk hias dan teknik sulaman dengan tujuan untuk meningkatkan mutu dan nilai jual kain itu sendiri.

Apresiasi Menghias Kain merupakan salah satu mata kuliah pada program studi Pendidikan Tata Busana di Universitas Negeri Jakarta. Mata kuliah ini membahas tentang proses penciptaan desain sulaman mulai dari menentukan sumber ide hingga membuatnya sesuai dengan fungsi benda dan teknik menghias kain yang dipilih. Adapun salah satu capaian pembelajaran mata kuliah (CPMK) adalah memiliki keterampilan menyulam teknik sulaman lekapan dan mampu memproduksi sulaman teknik lekapan (Harsuyanti, 2020).

\section{Sulaman Lekapan}

Sulaman lekapan adalah sulaman yang motif-motif hiasnya dibuat dari kain perca atau bahan lain kemudian dijahitkan dengan tusuk hias (Pulukadang, 2021). Dalam RPKPS dan Buku 
Ajar Apresiasi Menghias Tekstil (Utami, 2010), sulaman lekapan adalah Teknik menghias kain dengan cara melekapkan perca kain pada benda yang akan dihias. Perca kain dapat diletakan pada bagian baik atau bagian buruk benda yang akan dihias.

Jadi, dapat disimpulkan bahwa sulaman lekapan merupakan teknik menghias kain yang dilakukan dengan cara melekapkan kain pada benda yang akan dihias, kain diletakkan pada bagian baik atau bagian buruk kain yang kemudian dijahit atau disulam dengan menggunakan tusuk hias. Macam-macam sulaman lekapan antara lain sulaman aplikasi, sulaman inkrustrasi dan lekapan pada bahan yang sama. Namun, dalam penelitian ini, jenis sulaman lekapan yang akan dibahas di dalam modul adalah sulaman aplikasi.

Teknik menghias kain sulaman aplikasi ialah teknik menghias dengan melekapkan (melekatkan) kain yang telah dibentuk di atas kain lain (Pulukadang, 2021). Sulaman aplikasi merupakan meletakkan potongan kain pada bagian baik kain yang lain dengan menggunakan tusuk feston. Bahan yang dapat dihias dengan teknik aplikasi adalah sesuai dengan jenis bahan, baik polos, berbunga, kotak-kotak dan sebagainya (Utami, 2010).

Jadi, sulaman aplikasi adalah salah satu teknik lekapan yaitu melekatkan potongan kain yang diletakkan pada bagian baik kain yang dihias kemudian disulam dengan menggunakan tusuk feston. Bahan yang dapat dihias dengan teknik aplikasi adalah bahan yang termasuk ke dalam jenis kain tenun rapat seperti katun, blacu dan sebagainya. Motif bahan bisa berupa bahan polos, berbunga, kotak-kotak dan lain-lain sesuai desain yang diinginkan.

\section{HASIL DAN PEMBAHASAN}

Hasil penelitian ini dilakukan dengan tujuan mendeskripsikan data hasil penilaian terhadap modul mata kuliah Apresiasi Menghias Kain materi Sulaman Lekapan yaitu Sulaman Aplikasi. Penyusunan teks materi modul ini disusun dengan menggunakan program Microsoft Office (Microsoft Word) dan untuk pembuatan desain background, ilustrasi serta bagian sampul dibuat dengan menggunakan aplikasi Canva. Modul ini dikemas dalam bentuk cetak dengan spesifikasi meliputi kertas HVS dengan ukuran A4 (21 cm x $29.7 \mathrm{~cm})$, ukuran huruf teks naskah pada isi modul adalah 12 pt dengan jenis huruf Calibri. Sampul bagian depan yang mencerminkan garis besar isi materi sedangkan sampul belakang terdapat keterangan yang berisi garis besar isi materi (sinopsis). Sampul modul menggunakan kertas Art Paper yang kemudian akan dikemas secara keseluruhan dengan sampul SoftCover dengan laminating Glossy.
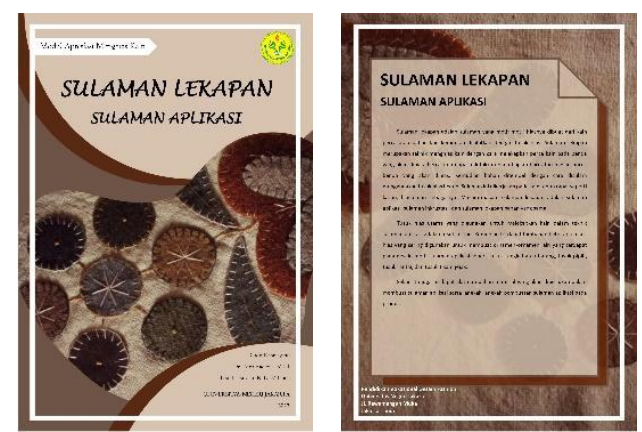

Gambar 4.1 Tampilan sampul depan dan belakang modul 


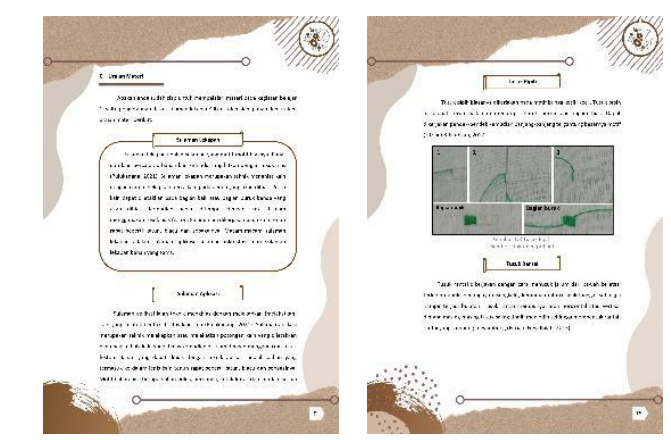

Gambar 4.2 Tampilan uraian materi modul

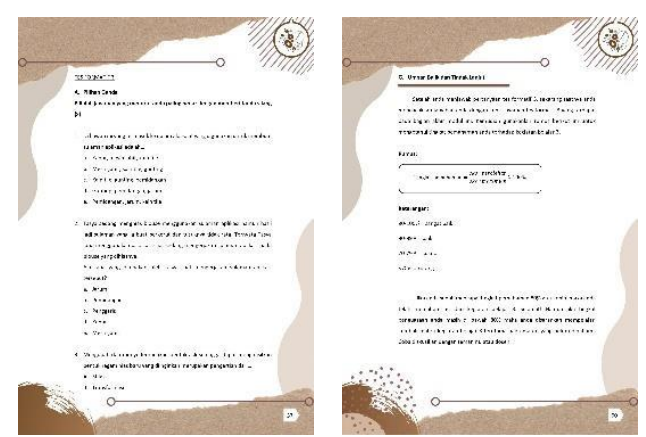

Gambar 4.3 Tampilan tes formatif dan umpan balik modul

Modul yang telah selesai dibuat kemudian dilakukan penilaian kepada panelis ahli berdasarkan pada karakteristik modul dan elemen mutu modul. Penilaian modul berdasarkan pada karakteristik modul dilakukan oleh 2 orang panelis ahli. Kemudian, penilaian modul berdasarkan elemen mutu modul dilakukan oleh 2 orang panelis ahli yang berbeda. Setelah melalui proses penilaian melalui angket, maka hasil penilaian karakteristik modul oleh panelis ahli adalah sebagai berikut:

Tabel 4.1 Tabel Skor Penilaian Modul Berdasarkan Karakteristik Modul

\begin{tabular}{|l|c|c|c|}
\hline \multicolumn{1}{|c|}{ Aspek } & $\begin{array}{c}\text { Jumlah } \\
\text { Pernyat } \\
\text { aan }\end{array}$ & $\begin{array}{c}\text { Jumla } \\
\mathbf{h} \\
\text { Skor }\end{array}$ & $\begin{array}{c}\text { Persent } \\
\text { ase (\%) }\end{array}$ \\
\hline Self Instruction & 14 & 106 & 94,75 \\
\hline Self Contained & 5 & 33 & 82,5 \\
\hline Stand Alone & 3 & 23 & 95,75 \\
\hline Adaptif & 4 & 29 & 90,63 \\
\hline User Friendly & 5 & 34 & 85 \\
\hline $\begin{array}{c}\text { Total Pernyataan = 31 } \times 2 \text { panelis } \\
=62\end{array}$ & \multicolumn{2}{|c}{ Total Skor $=225$} \\
\hline
\end{tabular}

$$
\text { rata }- \text { rata }=\frac{225}{62}=3,63
$$

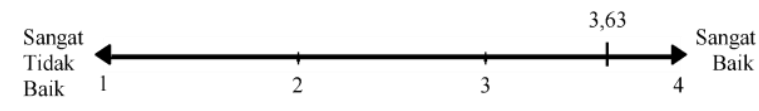


Persentase $\quad=3,63 / 4 \times 100 \%$

$$
=90,75 \%
$$

Berdasarkan hasil perhitungan pada penilaian panelis ahli berdasarkan karakteristik modul yang menilai 5 aspek berupa Self Instruction, Self Contained, Stand Alone, Adaptif, serta User Friendly didapatkan total nilai 3,63 sehingga berada pada kategori sangat baik. Dengan presentase total keseluruhan adalah 90,73\% dari yang diharapkan (100\%).

Kemudian penilaian panelis ahli berdasarkan elemen mutu modul adalah sebagai berikut:

Tabel 4.2 Tabel Skor Penilaian Modul Berdasarkan Elemen Mutu Modul

\begin{tabular}{|l|c|c|c|}
\hline \multicolumn{1}{|c|}{ Aspek } & $\begin{array}{c}\text { Jumlah } \\
\text { Pernyat } \\
\text { aan }\end{array}$ & $\begin{array}{c}\text { Juml } \\
\text { ah } \\
\text { Skor }\end{array}$ & $\begin{array}{c}\text { Persent } \\
\text { ase (\%) }\end{array}$ \\
\hline Format & 4 & 28 & 87,5 \\
\hline Organisasi & 7 & 52 & 92,75 \\
\hline Daya Tarik & 7 & 47 & 83,75 \\
\hline $\begin{array}{l}\text { Bentuk dan Ukuran } \\
\text { Huruf }\end{array}$ & 4 & 27 & 84,38 \\
\hline Ruang (Spasi Kosong) & 5 & 40 & 100 \\
\hline Konsistensi & 8 & 64 & 100 \\
\hline $\begin{array}{l}\text { Total Pernyataan = 35 } \times 2 \text { panelis } \\
70\end{array}$ & Total Skor $=258$ \\
\hline
\end{tabular}

rata - rata $=\frac{258}{70}=3,69$

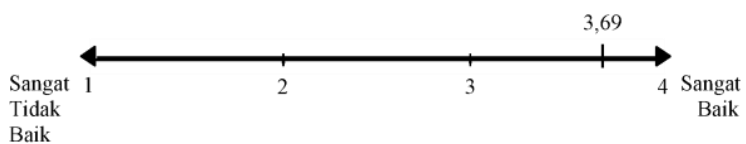

Persentase $\quad=3,69 / 4 \times 100 \%$

$=92,25 \%$

Berdasarkan hasil perhitungan pada penilaian panelis ahli berdasarkan elemen mutu modul dengan 6 aspek berupa format, organisasi, daya Tarik, bentuk dan ukuran huruf, ruang (spasi kosong), serta konsistensi didapatkan total nilai 3,69 untuk keseluruhan aspek penilaian elemen mutu modul, sehingga berada pada kategori Sangat Baik. Dengan presentase total keseluruhan adalah $92,25 \%$ dari yang diharapkan (100\%).

Setelah melalui proses penilaian oleh panelis ahli berdasarkan karakteristik modul dan elemen mutu modul, maka didapatkan hasil penilaian secara keseluruhan sebagai berikut:

Tabel 4.3 Tabel Skor Penilaian Modul Berdasarkan Aspek Karakteristik Modul dan Elemen Mutu Modul 


\begin{tabular}{|c|c|c|c|}
\hline Aspek & $\begin{array}{c}\text { Jumlah } \\
\text { Pernyat } \\
\text { aan }\end{array}$ & $\begin{array}{c}\text { Juml } \\
\text { ah } \\
\text { Skor }\end{array}$ & $\begin{array}{c}\text { Persent } \\
\text { ase (\%) }\end{array}$ \\
\hline Karakteristik Modul & 31 & 225 & 90,75 \\
\hline $\begin{array}{c}\text { Elemen Mutu Modul } \\
\text { Total Pernyataan }=66 \times 2 \\
\text { panelis = 132 }\end{array}$ & 258 & $\begin{array}{c}\text { Total Skor }= \\
483\end{array}$ \\
\hline \multicolumn{2}{|c|}{ rata - rata $=\frac{483}{132}=3,66$}
\end{tabular}

Persentase $=3,66 / 4 \times 100 \%$

$=91,5 \%$

Tabel 4.4 Tabel Kategori Persentase

\begin{tabular}{|c|c|c|}
\hline $\begin{array}{c}\text { Skala } \\
\text { Nilai }\end{array}$ & $\begin{array}{c}\text { Skor } \\
\text { Persentas } \\
\text { e (\%) }\end{array}$ & Tingkat Kategori \\
\hline 1 & $0-25$ & $\begin{array}{c}\text { Sangat Tidak } \\
\text { Baik }\end{array}$ \\
\hline 2 & $26-50$ & Tidak Baik \\
\hline 3 & $51-75$ & Baik \\
\hline 4 & $76-100$ & Sangat Baik \\
\hline
\end{tabular}

(Riduwan, 2010)

Berdasarkan hasil perhitungan pada penilaian panelis ahli yang menilai aspek karakteristik modul dan aspek elemen mutu modul didapatkan total nilai 3,66 sehingga berada pada kategori sangat baik, dengan persentase rata-rata keseluruhan penilaian adalah $91,5 \%$ dari yang diharapkan (100\%). Artinya modul sudah memenuhi karakteristik modul dan elemen mutu modul yaitu modul dapat dipelajari oleh mahasiswa secara mandiri, materi pembelajaran yang dibutuhkan sudah termuat dalam modul, memberikan kesempatan kepada mahasiswa untuk dapat mempelajari materi pembelajaran secara tuntas, modul dapat berdiri sendiri dimana modul dapat digunakan tanpa bergantung pada bahan ajar/media lain, modul cukup memenuhi kaidah user friendly atau bersahabat dengan pemakainya. Kemudian, penulisan dan penyusunan modul sudah baik dan sesuai seperti menggunakan format yang baik, pengorganisasian susunan modul sudah baik, desain modul sudah cukup menarik, menggunakan bentuk dan ukuran huruf yang cukup sesuai, memiliki ruang (spasi kosong) yang sesuai, serta memiliki konsistensi yang baik.

Penilaian pada karakteristik modul dengan nilai tertinggi diperoleh pada aspek Stand Alone yang memilliki nilai persentase terbesar yaitu $95,75 \%$ dari hasil yang diharapkan (100\%). Dan nilai terendah diperoleh pada aspek Self Contained dengan nilai persentase sebesar $82,5 \%$ dari hasil yang diharapkan (100\%). Sedangkan penilaian pada elemen mutu modul dengan nilai tertinggi diperoleh pada aspek ruang (spasi kosong) dan aspek konsistensi yang sama-sama memilliki nilai persentase terbesar yaitu $100 \%$ dari hasil yang diharapkan (100\%). Dan nilai terendah diperoleh pada aspek daya tarik dengan nilai presentase sebesar $83,75 \%$ dari hasil yang diharapkan (100\%). 


\section{KESIMPULAN}

Berdasarkan hasil penilaian panelis ahli pada aspek karakteristik modul dengan indikator berupa aspek Self Instruction, Self Contained, Stand Alone, Adaptif, dan User Friendly mendapat persentase sebesar $90,75 \%$ dari hasil yang diharapkan (100\%). Hal tersebut menunjukkan bahwa penilaian berdasarkan karakteristik modul berada pada kategori sangat baik.

Kemudian hasil penilaian panelis ahli pada aspek elemen mutu modul dengan indikator berupa aspek format, organisasi, daya Tarik, bentuk dan ukuran huruf, ruang (spasi kosong), serta konsistensi, mendapat persentase sebesar $92,25 \%$ dari hasil yang diharapkan (100\%). Hal tersebut menunjukkan bahwa penilaian berdasarkan elemen mutu modul berada pada kategori sangat baik.

Sehingga untuk penilaian modul apresiasi menghias kain materi sulaman lekapan pada keseluruhan aspek karakteristik modul dan elemen mutu modul yang meliputi Self Instruction, Self Contained, Stand Alone, Adaptif, User Friendly, format, organisasi, daya Tarik, bentuk dan ukuran huruf, ruang (spasi kosong), serta konsistensi secara keseluruhan mendapatkan persentase sebesar 91,5\% dari hasil yang diharapkan (100\%). Maka secara keseluruhan, hasil dari penialaian modul apresiasi menghias kain materi sulaman lekapan berada dalam kategori sangat baik yang artinya modul layak sebagai bahan ajar. Sehingga modul tersebut dapat dijadikan sebagai tambahan sumber belajar yang dapat dipelajari secara offline oleh mahasiswa dalam mempelajari dan memahami materi sulaman lekapan terutama sulaman aplikasi pada Program Studi Pendidikan Tata Busana Universitas Negeri Jakarta. Namun, ada baiknya apabila dilakukan tahapan pengembangan selanjutnya bagi modul sulaman lekapan ini.

Hasil dari pembuatan modul cetak dalam penelitian ini dapat dijadikan sebagai bahan ajar atau media pembelajaran untuk membantu dosen dalam menyampaikan materi pembelajaran sulaman lekapan khususnya sulaman aplikasi pada mata kuliah apresiasi menghias kain. Sehingga dapat membantu mahasiswa untuk dapat mempelajari dan memahami materi sulaman aplikasi secara mandiri. Modul ini juga dapat dikembangkan lagi menjadi e-modul, e-learning, video pembelajaran atau media pembelajaran lain oleh peneliti selanjutnya. Dengan melihat kekurangan-kekurangan yang ada pada modul berdasarkan masukan dari para panelis ahli, diharapkan peneliti selanjutnya dapat mengembangkan modul ini menjadi lebih baik dan lebih sempurna lagi.

\section{E. DAFTAR PUSTAKA}

Daryanto. (2013). Menyusun Modul. Yogyakarta: Gava Media.

Fatimah, S., \& Ramadhana, R. (2017). Pengembangan Modul Pembelajaran Berbasis Keterampilan Literasi. 6, 316-335.

Harsuyanti. (2020). RPS Apresiasi Menghias Kain.

Izzati, N., \& Fatikhah, I. (2015). Pengembangan Modul Pembelajaran Matematika Bermuatan Emotion Quotient Pada Pokok Bahasan Himpunan. Eduma: Mathematics Education Learning and Teaching, 4(2). https://doi.org/10.24235/eduma.v4i2.29

Najuah, Lukitoyo, P. S., \& Wirianti, W. (2020). Modul elektronik: Prosedur Penyusunan dan Aplikasinya. Yayasan Kita Menulis.

Ofianto, \& Ningsih, T. Z. (2021). Assesmen Keterampilan Berpikir Historis (Historical Thinking). Pamekasan: Duta Media Publishing.

Prihatiningtyas, S., \& Sholihah, F. N. (2020). Physics Learning By E-Module. Jombang: Universitas KH. A. Wahab Hasbullah. 
Pulukadang, W. R. (2021). Keterampilan Menghias Kain. Bandung : Titian Ilmu.

Puspitasari, A. D. (2019). Penerapan Media Pembelajaran Fisika Menggunakan Modul dan Modul Elektronik Pada Siswa SMA. Fisika, Jurnal Pendidikan, 7(1), 17-25.

Rahdiyanta, D. (2016). Teknik Penyusunan Modul Pembelajaran. Academia, 1-14.

Ramadhani, Y. R., Masrul, Ramadhani, R., Rahim, R., Tamrin, A. F., Daulay, J. S., Purba, A., Tasnim, Pasaribu, arsen N., AB, M. A., Agustin, T., Prianto, C., \& Simarmata, J. (2020). Metode dan Teknik Pembelajaran Inovatif. Yayasan Kita Menulis.

Riduwan. (2010). Dasar-Dasar Statistika. Bandung : Alfabeta.

Sugiyono. (2019). Metode Penelitian Pendidikan. Bandung : Alfabeta.

Triana, D. devi. (2020). Penilaian Kelas dalam pembelajaran Tari. Surabaya: CV. Jakad Media Publishing.

Utami, V. (2010). RPKPS dan Buku Ajar Apresiasi Menghias Tekstil.

Wulansari, E. W., Kantun, S., \& Suharso, P. (2018). Pengembangan E-Modul Pembelajaran Ekonomi Materi Pasar Modal Untuk Siswa Kelas Xi Ips Man 1 Jember Tahun Ajaran 2016/2017. JURNAL PENDIDIKAN EKONOMI: Jurnal IImiah Ilmu Pendidikan, IImu Ekonomi Dan IImu Sosial, 12(1), 1. https://doi.org/10.19184/jpe.v12i1.6463 